\title{
Evaluation of antipsychotic effect of methanolic extract of Ocimum sanctum leaves on laboratory animals
}

\author{
Kailash Sharma*, Milind Parle, Monu Yadav \\ Pharmacology Division, Department of Pharmaceutical Sciences, Guru Jambheshwar University of Science and Technology, Hisar (Haryana) India.
}

\begin{tabular}{|c|c|}
\hline ARTICLE INFO & ABSTRACT \\
\hline $\begin{array}{l}\text { Article history: } \\
\text { Received on: } 02 / 11 / 2015 \\
\text { Revised on: } 17 / 01 / 2016 \\
\text { Accepted on: } 10 / 02 / 2016 \\
\text { Available online: } 28 / 05 / 2016 \\
\end{array}$ & $\begin{array}{l}\text { Ocimum sanctum (Lamiaceae) commonly known as tulsi, is well known for its excellent nutritional and } \\
\text { medicinal values throughout the world. The present study was undertaken to test the effect of methanolic extract } \\
\text { of Ocimum sanctum leaves }(50,100 \text { and } 200 \mathrm{mg} / \mathrm{kg} \text {, p.o) on psychosis employing Ketamine induced stereotypic } \\
\text { behaviour in mice and Pole climbing avoidance in rats. Haloperidol }(1 \mathrm{mg} / \mathrm{kg} \text {, i.p.) and Olanzapine }(5 \mathrm{mg} / \mathrm{kg} \text {, i.p.) } \\
\text { are established antipsychotic drugs used as standard drugs in the present study. Effect of methanolic extract of }\end{array}$ \\
\hline $\begin{array}{l}\text { Key words: } \\
\text { Psychosis, anti-psychotics, } \\
\text { Ocimum sanctum, tulsi. }\end{array}$ & $\begin{array}{l}\text { Ocimum sanctum leaves (OS), on brain dopamine levels was also estimated. Methanolic extract of Ocimum } \\
\text { sanctum leaves }(50,100 \text { and } 200 \mathrm{mg} / \mathrm{kg} \text {, p.o), significantly reduced the Ketamine induced falling, weaving, head } \\
\text { bobbing and turning behavior in mice. Furthermore, it significantly delayed the latency time taken by the rats to } \\
\text { climb the pole. Haloperidol }(1 \mathrm{mg} / \mathrm{kg} \text {; i.p.) and Olanzapine }(5 \mathrm{mg} / \mathrm{kg} \text {, i.p.) significantly reduced the Ketamine } \\
\text { induced stereotypic behavior in mice and condition avoidance behavior in rats. Interestingly, Brain dopamine } \\
\text { level was significantly reduced by methanolic extract of Ocimum sanctum leaves. These findings, when taken } \\
\text { together indicate that methanolic extract of Ocimum sanctum leaves possesses anti-psychotic like property. }\end{array}$ \\
\hline
\end{tabular}

\section{INTRODUCTION}

Psychosis (schizophrenic, schizoaffective and affective illnesses) is a group of serious illnesses that affect the mind. It is a major debilitating, complex and costly illness that strikes $1 \%$ of the world's population. It is characterized by three general types of symptoms: Positive symptoms, Negative symptoms and Cognitive symptoms (Parle and Kadian, 2013). Positive symptoms refer to a loss of contact with reality and comprise of hallucinations, delusions and positive formal thought disorders. Negative symptoms refer to a diminution in or absence of normal behaviors and include flat affect, alogia, avolition and anhedonia (Parle and Sharma, 2013). Cognitive symptoms manifest as

\footnotetext{
* Corresponding Author

Kailash Sharma, Department of Pharmaceutical Sciences, Guru Jambheshwar University of Science \& Technology, Hisar (Haryana) 125001, India. Contact no.: +919812161998, +918930648896

Email: kailash.pharmacology@gmail.com
}

deficits in attention, learning and memory. Hyperactivation of mesolimbic pathway and dysfunction of mesocortical pathway generates imbalance in the serotonergic, dopaminergic, GABAergic and glutamatergic neurotransmission in certain region of brain, are major reason of psychosis. Other reasons of psychosis can be attributed to heredity, stress, oxidative stress, NMDA receptor antagonists, drug abuse and traumatic injury. Antipsychotics are used for the management of psychosis are typical and atypical (Yadav et al., 2015). Adverse effects due to the use of typical antipsychotics is extra-pyramidal side effects whereas, atypical antipsychotic possess lesser extra-pyramidal side effects. In spite of the availability of a number of drugs for treatment of psychosis, however, at present there is no satisfactory remedy available for prevention and management of psychosis. Herbals medicines are tremendously considered to be less toxic than synthetic ones. Now-a-day, there has been growing interest in the therapeutic use of plants because of their safe and economical use (Sharma et al., 2015). Therefore, the aim of our study was to explore the potential of plant in the management of psychosis. 


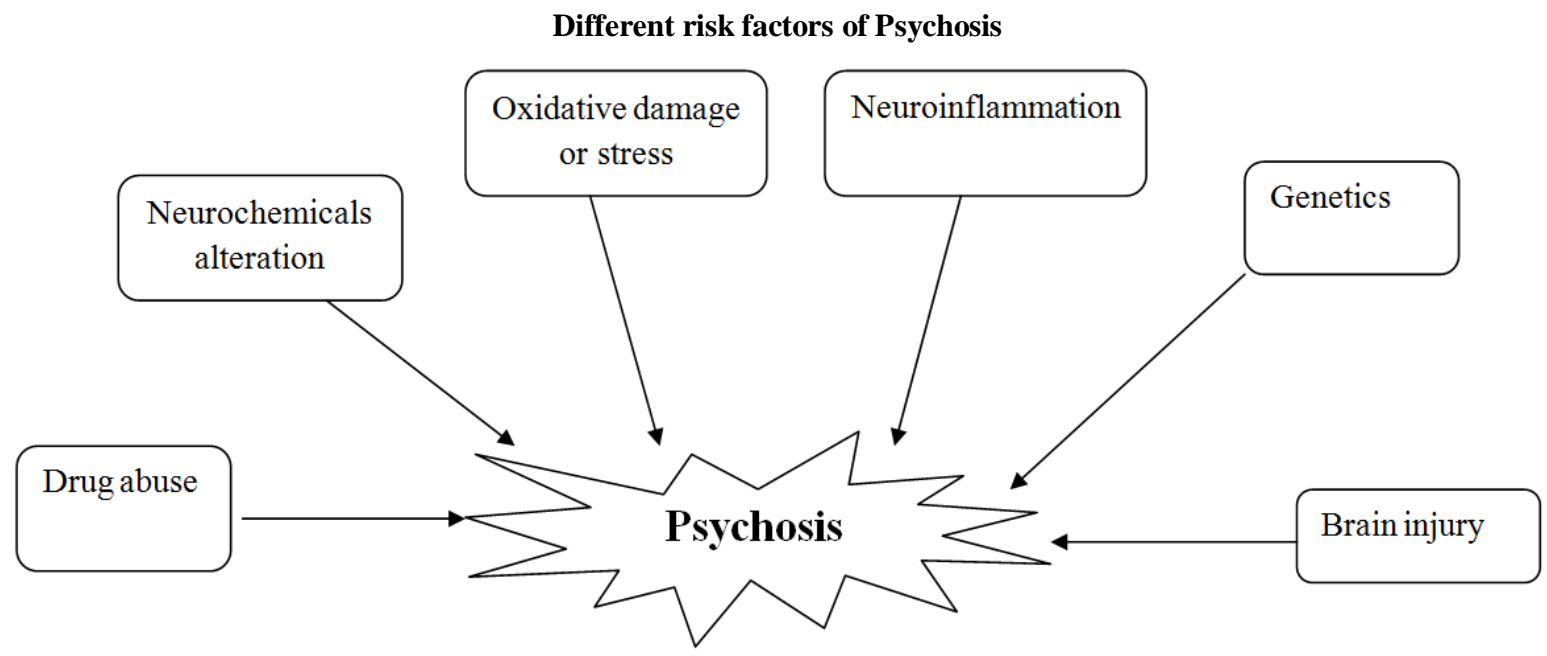

Ocimum sanctum (Lamiaceae) commonly known as tulsi, is well known for its excellent nutritional and medicinal values throughout the world. Different parts of Ocimum sanctum have been reported for their diverse ranges of pharmacological actions including anti-oxidant, anti-stress, anti-convulsant, antiinflammatory, analgesic, and immunomodulatory. Phytoconstituents isolated from various parts of the tulsi plant are eugenol, cardinene, cubenol, borneol, linolenic acid, oleic acid, palmitric acid, steric acid, vallinin, vicenin, vitexin, vllinin acid, orientin, circineol, gallic acid, vitamin A, vitamin C, phosphrous and iron (Kadian and Parle 2012; Triveni et al., 2013). Therefore, we aimed to investigate the effect of methanolic extract of Ocimum sanctum Leaves using Ketamine induced stereotypic behavior in mice and Pole climb avoidance behavior in rats.

\section{MATERIALS AND METHODS}

\section{Plant material}

The fresh leaves of tulsi were procured from Guru Jambheshwar university campus. The plant was identified and authenticated from National Herbarium of Cultivated Plants (NHCP), Division of Plant Exploration and Germplasm Collection, National Bureau of Plant Genetic Resources, New Delhi (vide. № NHCP/NBPGR/2013-3/486). Methanolic extract of Ocimum sanctum leaves (OS) was administered in different doses $(50,100$ and $200 \mathrm{mg} / \mathrm{kg}$, p.o) to mice and rats.

\section{Extraction}

The shade dried and powdered leaves of Ocimum sanctum (1000 gm) was Soxhlet extracted with methanol for $72 \mathrm{~h}$. The extract was evaporated to dryness (Yield: $33 \mathrm{~g} / \mathrm{kg}$ ). This extract was suspended into $2 \%$ tween 80 .

\section{Experimental animals}

A total of 42 Swiss albino mice of either sex, weighing 25-30g and 30 male Wistar rats, weighing 120-150g were procured from Disease Free Small Animal House, Lala Lajpat Rai University of Veterinary and Animal Sciences (LUVAS), Hisar,
Haryana (India). The experimental protocol was approved by Institutional Animals Ethics Committee (IAEC), Ministry of Environment and Forests, Government of India, New Delhi, India (Registration №. 0436). Animals were housed under standard conditions of temperature $\left(24 \pm 2^{\circ} \mathrm{C}\right)$ and relative humidity (30$70 \%$ ) with a 12:12 light: dark cycle. The animals were acclimatized for at least 7 days to the laboratory conditions before behavioral experiments. Experiments were carried out between 09:00 h - 17:00 h. Mice and rats were divided into 7 groups and 5 groups respectively. Separate group of animals were used for each observation. Each group comprised of a minimum 6 animals.

\section{Drugs protocol}

Olanzapine (Ranbaxy Laboratories, India), Haloperidol (RPG Science Pharmaceutical Pvt. Ltd) and Ketamine (Neon Pharmaceutical Pvt. Ltd) were used in the present study.

\section{Drugs solution}

Olanzapine was suspended in a vehicle consisting of 5\% tween-80 in $0.9 \%$ saline. Haloperidol and Ketamine were separately diluted in $0.9 \%$ saline. Whereas, methanolic extract of Ocimum sanctum leaves was dissolved in $2 \%$ of tween-80 just before administration to the animals.

\section{Experimental protocol}

Ketamine-induced stereotypic behaviour in mice

Saline or Saline + Ketamine or Haloperidol + Ketamine or Olanzapine + Ketamine or Test drug + Ketamine in different groups of animals

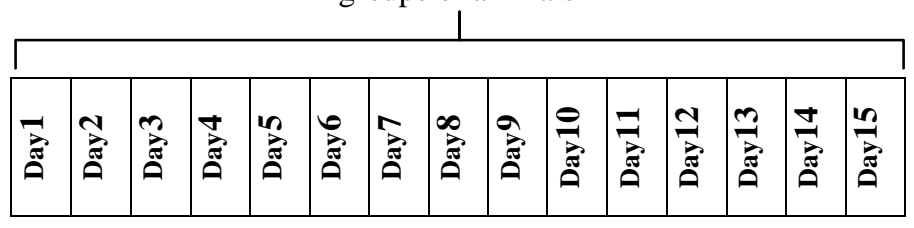

Group I (Control group): Normal saline was administered i.p for 15 successive days to mice. On $15^{\text {th }}$ day, number of stereotypy was recorded at $0,10,20,30$ and 60 minutes. 
Group II (Ketamine group): Ketamine (50mg/kg) was injected to mice for 15 successive days. After 20 min of last dose of Ketamine administration on $15^{\text {th }}$ day, the mice were exposed into the cage and the number of stereotypic behavior was recorded at $0,10,20,30$ and 60 minutes.

Group III \& Groups IV (Standard groups): Haloperidol $(1 \mathrm{mg} / \mathrm{kg})$ and Olanzapine $(5 \mathrm{mg} / \mathrm{kg})$ were administered i.p for 15 successive days respectively. After $60 \mathrm{~min}$ of last dose of Haloperidol and Olanzapine administration on $15^{\text {th }}$ day, the mice were exposed into the cage and the number of stereotypic behavior were recorded at $0,10,20,30$ and 60 minutes.

Groups V VI \& Group VII (Test groups): Ocimum sanctum extract $(50,100$ and $200 \mathrm{mg} / \mathrm{kg}$ ) were administered peroral for 15 successive days. On $15^{\text {th }}$ day, mice were exposed into the cage and the number of stereotypic behaviour was recorded at $0,10,20,30$ and 60 minutes.

\section{Pole climbing avoidance in rats}

Saline or Haloperidol or Test drug in different groups of rats

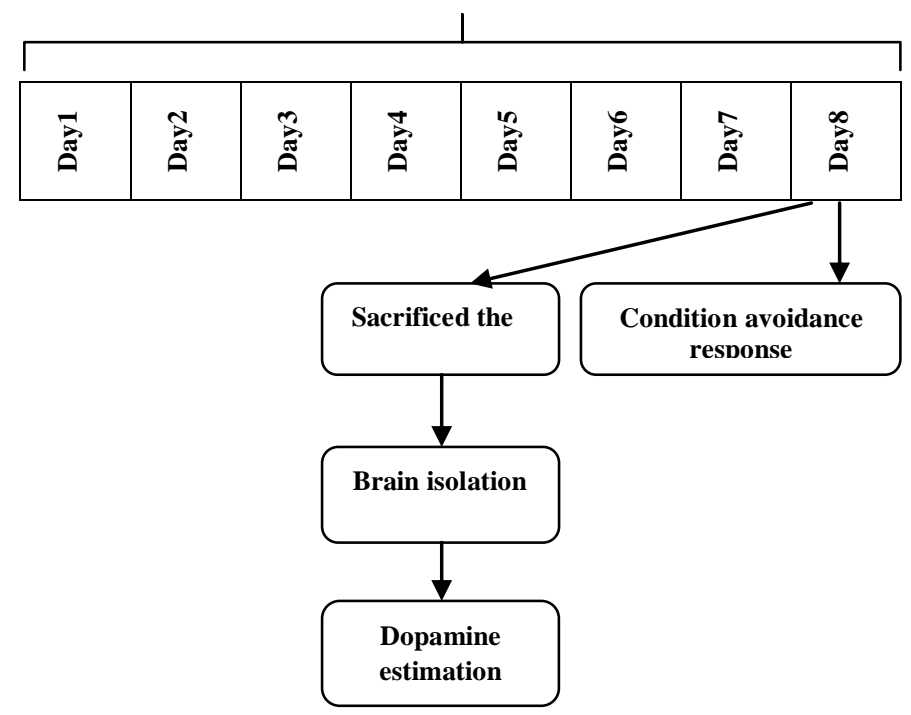

Group VIII (Control group): Normal saline was administered i.p for 8 successive days. Latency to climb the pole was recorded on $8^{\text {th }}$ day.

Group IX (Standard group): Haloperidol (1mg/kg) was administered i.p for 8 successive days respectively. Latency to climb the pole was recorded on $8^{\text {th }}$ day.

Groups X, XI \& Group XII (Test groups): Ocimum sanctum extract $(50,100$ and $200 \mathrm{mg} / \mathrm{kg}$ ) were administered peroral for 8 successive days. Latency to climb the pole was recorded on $8^{\text {th }}$ day.

\section{Biochemical estimation}

\section{Collection of brain samples}

The animals were sacrificed by cervical decapitation under light anaesthesia on the 8th day $90 \mathrm{~min}$ after drugs administration. Immediately after the decapitation, the whole brain was dissected out. Weighed quantity of tissue was homogenized in $0.1 \mathrm{ml}$ hydrochloric acid - butanol, $(0.85 \mathrm{ml}$ of $37 \%$ hydrochloric acid in one liter $n$ - butanol for spectroscopy) for $1 \mathrm{~min}$ in a cool environment.

The sample was then centrifuged for $10 \mathrm{~min}$ at 2,000 rpm. $0.08 \mathrm{ml}$ of supernatant phase was removed and added to an Eppendorf reagent tube containing $0.2 \mathrm{ml}$ of heptane (for spectroscopy) and $0.025 \mathrm{ml}$ of $0.1 \mathrm{M}$ hydrochloric acid. After 10 min of vigorous shaking, the tube was centrifuged under same conditions to separate two phases. Upper organic phase was discarded and the aqueous phase $(0.02 \mathrm{ml})$ was used for estimation of Dopamine assay (Schlumpf et al., 1974).

\section{Estimation of brain dopamine levels}

To $0.02 \mathrm{ml}$ of aqueous, $0.05 \mathrm{ml} 0.4 \mathrm{M}$ EDTA and $0.01 \mathrm{ml}$ Sodium acetate buffer ( $\mathrm{pH}$ 6.9) were added, followed by $0.01 \mathrm{ml}$ iodine solution $(0.1 \mathrm{M}$ in ethanol) for oxidation. The reaction was stopped after two minutes by addition of $0.01 \mathrm{ml} \mathrm{Na} 2 \mathrm{SO} 3$ in $5 \mathrm{M}$ $\mathrm{NaOH}(0.5 \mathrm{~g} \mathrm{Na} 2 \mathrm{SO} 3$ in $2 \mathrm{ml} \mathrm{H} 2 \mathrm{O}+18 \mathrm{ml} 5 \mathrm{M} \mathrm{NaOH})$. Acetic acid $(0.01 \mathrm{ml}, 10 \mathrm{M})$ was added 1.5 minutes later. Then the solution was heated to $100 \mathrm{oC}$ for 6 minutes. When the sample again reached room temperature, excitation and emission spectra were read from the spectrofluorimeter at 330/375nm (Schlumpf et al., 1974).

Internal Standard was prepared by adding $500 \mu \mathrm{g} / \mathrm{ml}$ of dopamine in distilled water: $\mathrm{HCl}$-butanol in 1:2 ratios and following the whole above mentioned procedure. Tissue blanks and internal reagent blank were prepared by adding the reagents of the oxidation step in reversed order (sodium sulphite before iodine).

\section{STATISTICAL ANALYSIS}

Results were expressed as mean \pm SEM. Significant differences between groups were determined using one-way ANOVA followed by Dunnett's test. Differences between data sets were considered as significant when $\mathrm{p}<0.05$ and $\mathrm{p}<0.01$.

\section{RESULTS}

Effect of methanolic extract of Ocimum sanctum Leaves (OS) on ketamine-induced stereotypic behavior of mice

Ketamine $(50 \mathrm{mg} / \mathrm{kg}$, i.p.) produced stereotypic behaviour (turning, weaving, head-bobbing and falling) in mice. OS (100 and $200 \mathrm{mg} / \mathrm{kg}$, p.o.), when administered to mice for 15 successive days significantly $(\mathrm{p}<0.01)$ decreased turning and falling behavior as compared to ketamine group. Similarly, OS (50, 100 and $200 \mathrm{mg} / \mathrm{kg}$, p.o.), when administered to mice for 15 successive days significantly $(\mathrm{p}<0.01)$ decreased head-bobbing and weaving behavior as compared to ketamine group.

Haloperidol $(1 \mathrm{mg} / \mathrm{kg} ;$ i.p. $)$ and Olanzapine $(5 \mathrm{mg} / \mathrm{kg}$, i.p $)$ an established anti-psychotic agents remarkably $(\mathrm{p}<0.01)$ reduced these stereotypic behavior respectively (Figure 1, 2, $3 \& 4$ ). 


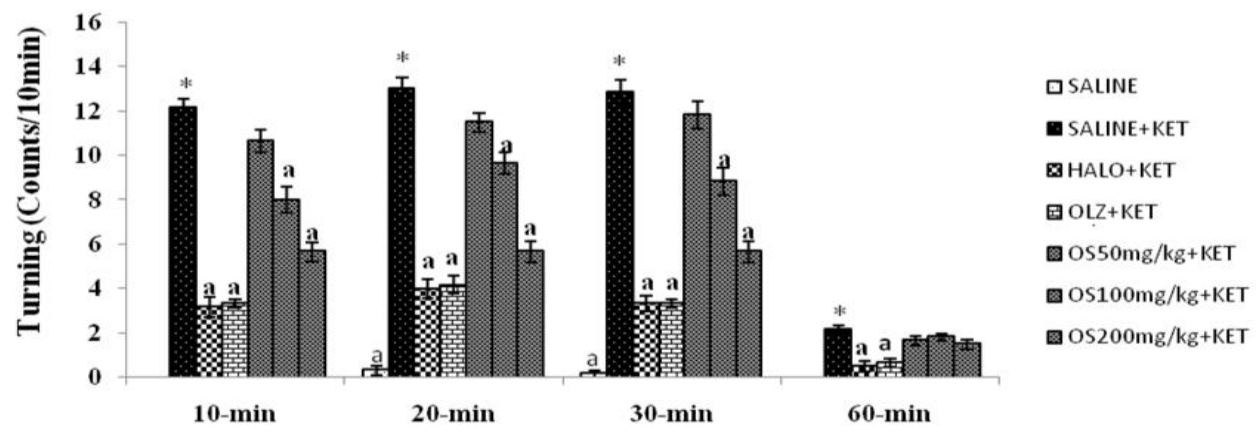

Fig. 1: Effect of OS on turning behavior of mice. Values are in mean \pm SEM $(n=6)$. One way ANOVA followed by Dunnett's t-test. * denotes $p<0.01$ as compared to control group. a denotes $\mathrm{p}<0.01$ as compared to ketamine group. OS = Methanolic extract of Ocimum sanctum Leaves (50, $100 \& 200 \mathrm{mg} / \mathrm{kg}$, p.o) Ket $=$ ketamine $(50 \mathrm{mg} / \mathrm{kg}$, i.p), Halo = haloperidol $(1 \mathrm{mg} / \mathrm{kg}$, i.p), Olz = Olanzapine $(5 \mathrm{mg} / \mathrm{kg}$, i.p) were dissolved in normal saline and administered for 15 Successive days to rats.

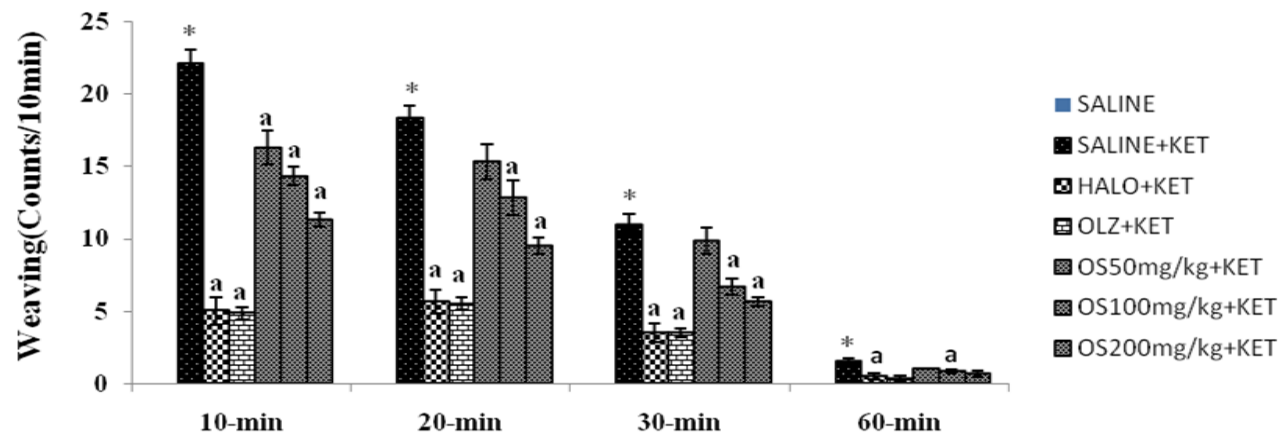

Fig. 2: Effect of OS on weaving behavior of mice. Values are in mean \pm SEM $(\mathrm{n}=6)$. One way ANOVA followed by Dunnett's t-test. * denotes $\mathrm{p}<0.01$ as compared to control group. a denotes $\mathrm{p}<0.01$ as compared to ketamine group.

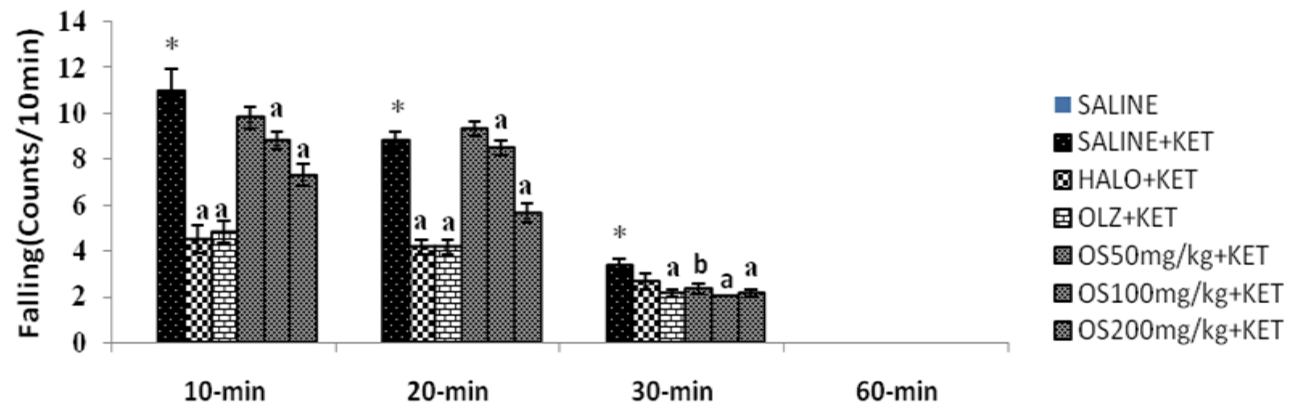

Fig. 3: Effect of OS on falling behavior of mice. Values are in mean \pm SEM $(n=6)$. One way ANOVA followed by Dunnett's $t$-test. $*$ denotes $p<0.01$ as compared to control group. a denotes $\mathrm{p}<0.01$ as compared to ketamine group.

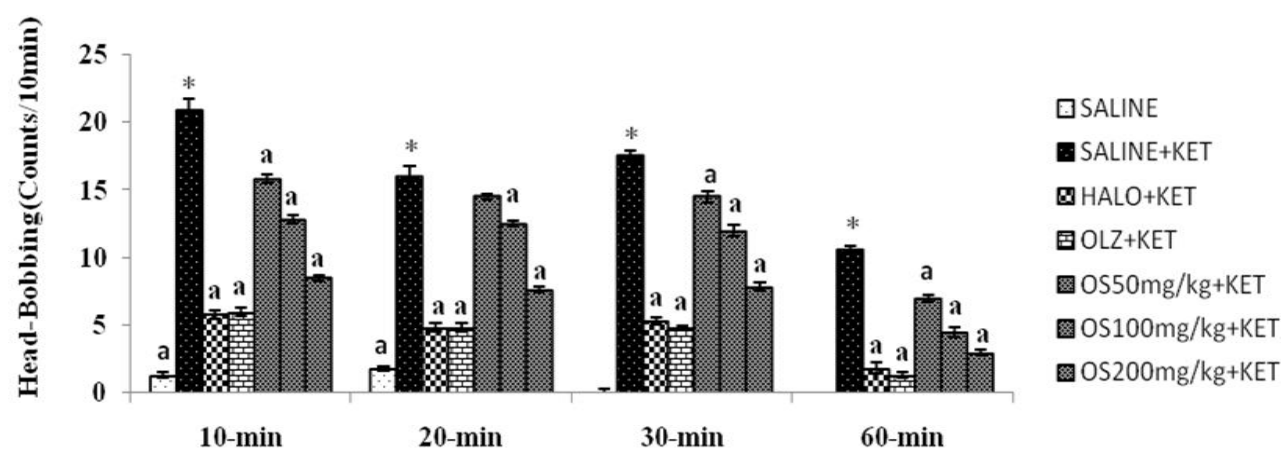

Fig. 4: Effect of OS on head-bobbing behavior of mice. Values are in mean \pm SEM $(n=6)$. One way ANOVA followed by Dunnett's $t$-test. * denotes $p<0.01$ as compared to control group. a denotes $\mathrm{p}<0.01$ as compared to ketamine group. 


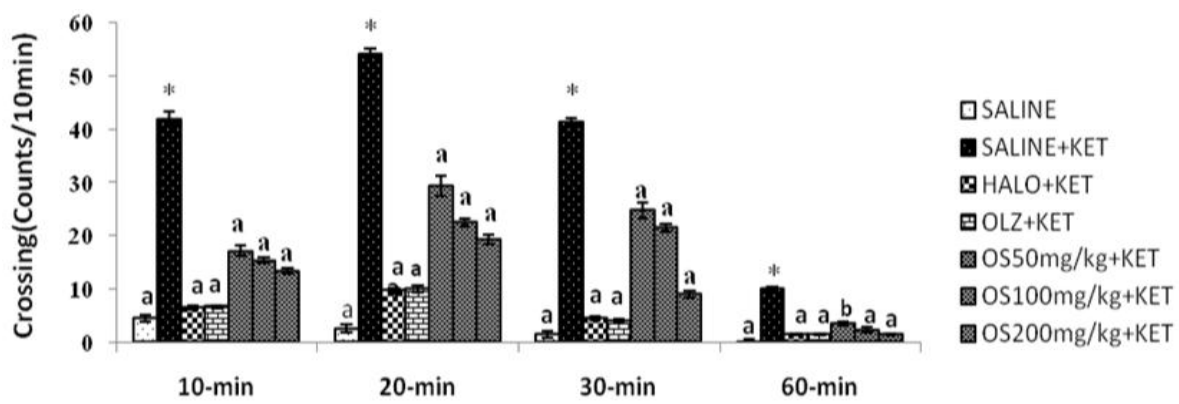

Fig. 5: Effect of OS on locomotion behavior of mice. Values are in mean \pm SEM $(n=6)$. One way ANOVA followed by Dunnett's t-test. * denotes $p<0.01$ as compared to control group. a denotes $\mathrm{p}<0.01$ as compared to ketamine group. $\mathrm{b}$ denotes $\mathrm{p}<0.05$ as compared to ketamine group.

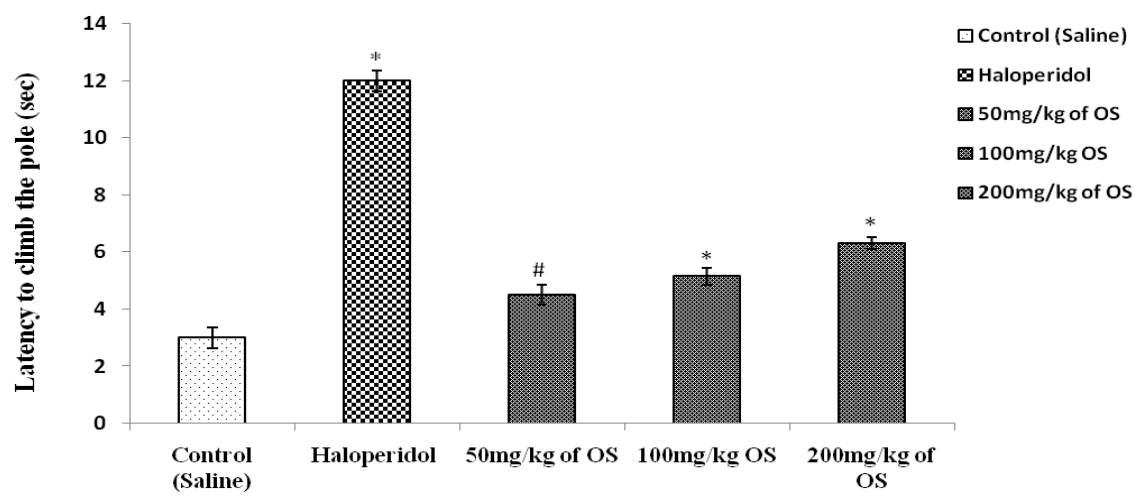

Fig. 6: Effect of OS on pole climb avoidance in rats. Values are in mean $\pm \operatorname{SEM}(n=6)$. One way ANOVA followed by Dunnett's t-test. $*$ denotes $p<0.01$ as compared to control group. \# denotes $\mathrm{p}<0.05$ as compared to control group.

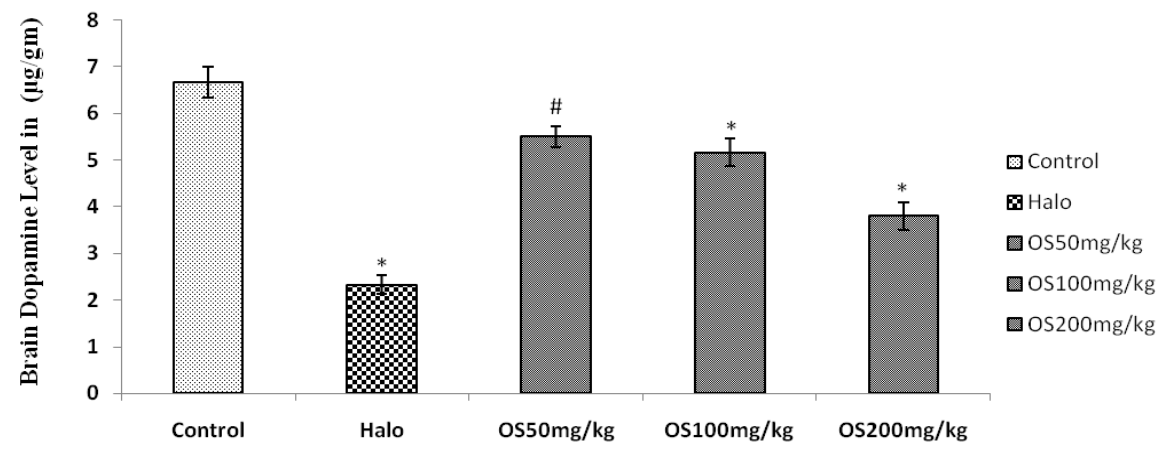

Fig. 7: Effect of OS on brain dopamine level of rats. Values are in mean \pm SEM $(n=6)$. One way ANOVA followed by Dunnett's t-test. * denotes $p<0.01$ as compared to control group. \# denotes $\mathrm{p}<0.05$ as compared to control group.

\section{Effect of Ocimum sanctum extract (OS) on locomotor activity}

Locomotor activity (counts) of the mice was measured every $10 \mathrm{~min}$ for $60 \mathrm{~min}$ with actophotometer. Significant decreased in locomotor activity has been observed in treated groups (Figure 5).

\section{Effect of methanolic extract of Ocimum sanctum Leaves (OS) on Pole climbing avoidance in rats}

Administration of OS $(50 \mathrm{mg} / \mathrm{kg}, \mathrm{p} . \mathrm{o})$ for eight successive days significantly $(\mathrm{p}<0.05)$ inhibited the conditioned avoidance response in rats as indicated by increased time spent on the grid floor of the chamber. However, OS (100 and $200 \mathrm{mg} / \mathrm{kg}$, p.o) were remarkably $(p<0.01)$ inhibiting the conditioned avoidance response as compared to control. Haloperidol $(1 \mathrm{mg} / \mathrm{kg}$; i.p.) remarkably $(\mathrm{p}<0.01)$ reduced the conditioned avoidance response inhibiting the conditioned avoidance response (Figure 6).

\section{Effect of methanolic extract of Ocimum sanctum Leaves (OS) on brain dopamine levels of rats}

Administration of $O S$ (50 and $100 \mathrm{mg} / \mathrm{kg}, 200 \mathrm{mg} / \mathrm{kg}$ p.o) for 8 consecutive days showed significant decrease in brain dopamine level as compared to control group (Figure 7). 
Possible protective mechanism of action of Ocimum sanctum

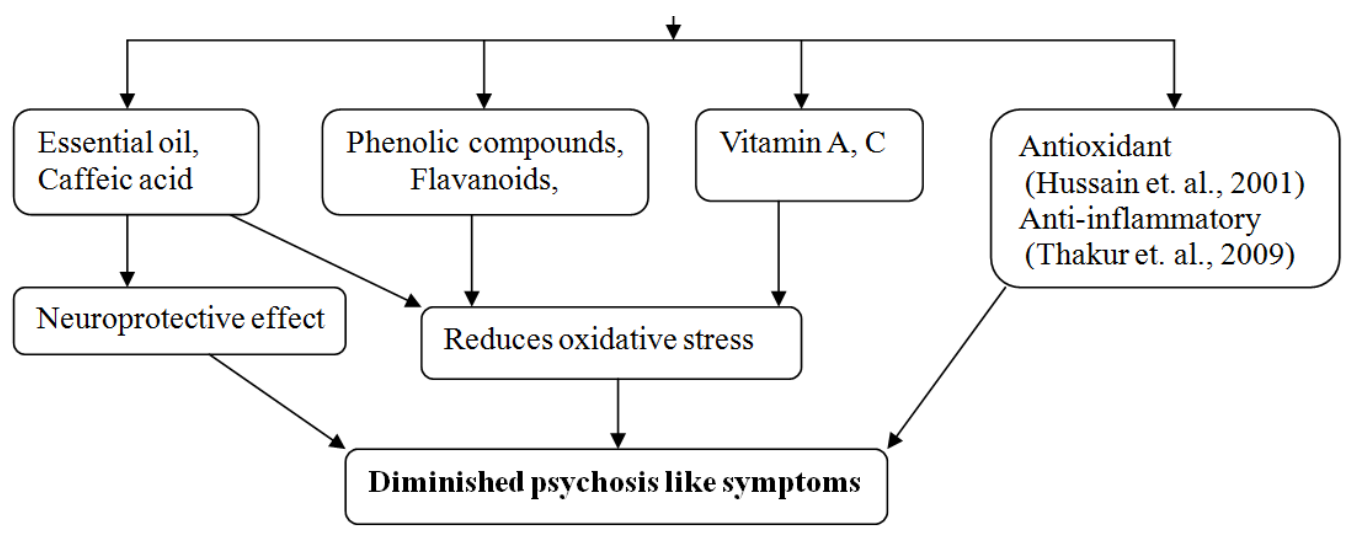

\section{DISCUSSION AND CONCLUSION}

In the present study, we have focused upon the effects of methanolic extract of Ocimum sanctum leaves on psychosis employing ketamine induced stereotypic behaviour in mice and pole climbing avoidance in rats. Dopamine, GABA, glutamate, 5HT and norepinephrine levels imbalance in certain areas of brain causes psychotic symptoms (Parle and Sharma, 2013). Herbal drugs due to its antioxidant property and lesser side-effects remain the ideal choice in comparison to synthetic drugs. Ocimum sanctum is the tremendous source of excellent phytoconstituents and phytonutrients, which have antioxidant, anti-inflammatory and neuroprotective effects (Hussain et al., 2001; Thakur et al., 2009). Therefore, the present study was designed to investigate antipsychotic like activity of methanolic extract of Ocimum sanctum leaves. Ketamine is a NMDA receptor antagonist, which induces characteristic stereotype behavior mediated by the hyperactivity of dopaminergic mechanism in the nigrostriatal and mesolimbic pathway (Kapur and Seeman, 2002). These stereotype behaviours are considered as abnormal behaviours. Inhibition of Ketamine induced stereotypic behaviours is regarded as a very selective test for screening of antipsychotic activity. In the present, it has been found that methanolic extract of Ocimum sanctum leaves significantly reduced the ketamine induced stereotypic behaviors in mice when administered to mice for 15 successive days. This confirmed that that methanolic extract of Ocimum sanctum leaves has significant antipsychotic like activity. Pole climb avoidance behavior mainly affects cognitive behavior by mesocortical pathway of dopaminergic neurons (Cook and Catania, 1964). It is an avoidance escape procedure used to separate neuroleptics from sedatives and anxiolytics. Whereas, sedative compounds suppress both avoidance and escape responding at approximately the same doses, neuroleptic drugs reduce avoidance responding at lower doses than those affecting escape responding. In our study, when methanolic extract of Ocimum sanctum administered for 8 successive days significantly delayed time taken by the rats to climb the pole. This revealed that antipsychotic potential of methanolic extract of Ocimum sanctum.
Methanolic extract of Ocimum sanctum leaves also decreases the locomotor activity. Haloperidol and Olanzapine remarkably diminished stereotypic behavior induced by Ketamine in mice and conditioned avoidance behavior in rats. In biochemical studies, methanolic extract of Ocimum sanctum significantly decreased the brain dopamine levels.

These findings reveal the antipsychotic effect of methanolic extract of Ocimum sanctum leaves. The antioxidant (Hussain et al., 2001) and anti-inflammatory (Thakur and Pitre, 2009) effect of Ocimum sanctum, may also be contributing to the anti-psychotic effect. Ocimum sanctum is known to contain higher concentration of flavonoids, essential oil, Caffeic acid and vitamins. This shows that flavonoid contents and vitamins in Ocimum sanctum may be responsible for the antipsychotic activity. Furthermore, it may act synergistically or other minor constituents may also contribute to the observed activity.

When, these observations taken collectively suggest that methanolic extract of Ocimum sanctum leaves has promising antipsychotic effect. Therefore, it is worthwhile to explore the usefulness of these plants in the management of various mental disorders.

\section{ACKNOWLEDGEMENTS}

We would like to thank All India council for Technical Education (AICTE), New Delhi for financial support in the form of fellowship.

\section{REFERENCES}

Cook L and Catania AC. Effects of drugs on avoidance and escape behaviour. Federation Proceedings, 1964; 23: 818-835.

Hussain MA EH, Jamil K and Rao M. Eshrat Halim MA H, Kaiser J, and Mala R. Hypoglycaemic, hypolipidemic and antioxidant properties of tulsi (Ocimum sanctum linn) on streptozotocin induced diabetes in rats. Indian J Clin Biochem, 2001; 16(2): 190-194.

Kadian $\mathrm{R}$ and Parle $\mathrm{M}$. Therapeutic potential and phytopharmacology of tulsi. Int. J. Pharm. Life Sci, 2012; 3: 1858-1867. 
Kapur S and Seeman P. NMDA receptor antagonists ketamine and PCP have direct effects on the dopamine D2 and serotonin 5-HT2 receptors-implications for models of schizophrenia. Mol Psychiatry, 2002; 7: $837-844$

Thakur K and Pitre KS. Anti-Inflammatory activity of extracted eugenol from Ocimum sanctum L. Leaves. Rasayana J. Chem, 2009; 2: 472-474.

Parle M and Kadian R. Behavioral models of psychosis. Int. Res. J. Pharm, 2013; 7: 26-30.

Parle $M$ and Sharma K. Schizophrenia: A Review. Int. Res. J. Pharm, 2013; 4: 52-55.

Parle M and Sharma K. Biomarker and causative factor of schizophrenia. Int. Res. J. Pharm, 2013; 4: 78-85.

Parle $\mathrm{M}$ and Sharma K. Schizophrenia: A Review. Int. Res. J. Pharm, 2013; 4: 52-55

Schlumpf M, Lichtensteiger W, Langemann H, Waser GP and Hefti F. A fluorometric micromethod for the simultaneous determination of serotonin, noradrenaline and dopamine in milligram amounts of brain tissue. Biochem Pharmacol, 1974; 23:2437-2446.
Sharma K, Preeti, Parle M and Monu. Medicinal plants possessing anxiolytic activity: A brief review. Der Pharmacia Sinica, 2015; 6(5): 1-7

Triveni, Kumar K, Singh A K, Kumar R, Gupta V and Tripathi K. Ocimum sanctum Linn: A Review on Phytopharmacology and Therapeutic Potential of Tulsi. J. Pharm. Phytopharmacol. Res, 2013; 3 (2): 148-151.

Yadav M, Parle, Kadian $\mathrm{M}$ and Sharma K. A review on psychosis and anti-psychotic plants. Asian J Pharm Clin Res, 2015; 8: 2428 .

\section{How to cite this article:}

Sharma K, Parle M, Yadav M.,Evaluation of antipsychotic effect of methanolic extract of Ocimum sanctum leaves on laboratory animals. J App Pharm Sci, 2016; 6 (05): 171-177. 